\title{
Antifungal Methylphenone Derivatives and 5-Methylcoumarins from Mutisia friesiana
}

Carmen I. Viturro ${ }^{\mathrm{a}}$, Juana R. de la Fuente ${ }^{\mathrm{b}}$, and Marta S. Maier ${ }^{\mathrm{c}, *}$

a Facultad de Ingeniería, Universidad Nacional de Jujuy, Gorriti 237, 4600 S. S. de Jujuy, Jujuy, Argentina

b Facultad de Ciencias Exactas, Universidad Nacional de Salta, Buenos Aires 177, 4400 Salta, Salta, Argentina

c Departamento de Química Orgánica, Facultad de Ciencias Exactas y Naturales, Universidad de Buenos Aires, Ciudad Universitaria, 1428 Buenos Aires, Argentina. Fax: 541145763346. E-mail: maier@qo.fcen.uba.ar

* Author for correspondence and reprint requests

Z. Naturforsch. 58c, 533-540 (2003); received November 6, 2002/February 27, 2003

In addition to the known mutisicoumarin A, the aerial parts of the shrub Mutisia friesiana afforded five new methylphenones, two new 5-methylcoumarins and a new related chromone. Their structures were elucidated by spectroscopic methods. ${ }^{13} \mathrm{C}$ NMR data for mutisicoumarin A are reported for the first time. Mutisiphenones A and B and mutisicoumarin A showed antifungal activity against the phytopathogenic fungus Cladosporium cucumerinum.

Key words: Mutisia friesiana, 5-Methylcoumarins, Methylphenone Derivatives

\section{Introduction}

Mutisia friesiana (family Asteraceae, tribe Mutisieae, subtribe Mutisiinae) is a perennial shrub native of S. Bolivia and N. W. Argentina that grows at $3500-4000 \mathrm{~m}$ above sea level. The infusion of this species is used in folk medicine as a remedy against chronic cough, respiratory diseases and stomach pains (Giberti, 1983). Previous studies on this species allowed us to identify more than 100 compounds in its essential oil (Viturro and de la Fuente, 2000). Bioassay-guided fractionation of the aqueous extract of $M$. friesiana afforded caffeic acid derivatives and flavonoids as the main active compounds showing radical scavenging activity (Viturro et al., 1999). Recently, we have reported the isolation and structural elucidation of two antifungal diastereomeric furanones described for the first time from a natural source (Viturro et al., 2001). Following our studies on $M$. friesiana, we now report the isolation of five new methylphenones (1-5), two new 5-methylcoumarins (7 and 8) and a new related chromone (9).

\section{Results and Discussion}

The $\mathrm{CHCl}_{3}$ fraction of the methanolic extract of the aerial parts of $M$. friesiana afforded eight new compounds 1-5 and 7-9, together with the known mutisicoumarin A (6), previously isolated from $M$. spinosa (Zdero et al., 1986).

Mutisiphenone A (1) was isolated as a colorless oil. Its ${ }^{1} \mathrm{H}$ NMR spectrum (Table I) showed signals at $6.72,6.82$ and $7.25 \mathrm{ppm}$, whose coupling pattern indicated a 1,2,3-trisubstituted aromatic compound (Balbaa et al., 1980). In addition to a signal for an aromatic methyl group at $2.58 \mathrm{ppm}$, a broad singlet at $11.59 \mathrm{ppm}$ indicated a phenolic hydroxyl group. The IR spectrum afforded absorptions at $3600-2600$ and $1665 \mathrm{~cm}^{-1}$, characteristic of a strong intramolecular bonding in an $o$-hydroxyacetophenone derivative (Zdero et al., 1986). A strongly deshielded signal of a carbonyl group at $208.6 \mathrm{ppm}$ in the ${ }^{13} \mathrm{C}$ NMR spectrum (Table II) of 1 was consistent with this substitution pattern (Breitmaier and Voelter, 1987). The molecular formula of Mutisiphenone A (1) was determined as $\mathrm{C}_{19} \mathrm{H}_{26} \mathrm{O}_{2}(\mathrm{~m} / z$ 286) by pseudomolecular ions at $m / z \quad 287[\mathrm{M}+\mathrm{H}]^{+}$in the FABMS (positive ion mode) and at $m / z 285[\mathrm{M}-\mathrm{H}]^{-}$in the FABMS (negative ion mode). These data and the ${ }^{1} \mathrm{H}$ and ${ }^{13} \mathrm{C}$ NMR spectra of $\mathbf{1}$ suggested a hydrocarbonated monoterpene moiety attached to $\mathrm{C}-3$. The ${ }^{1} \mathrm{H}$ NMR spectrum also showed the presence of three allylic methyl signals at $1.59,1.63$ and $1.67 \mathrm{ppm}$. The ${ }^{1} \mathrm{H}_{-}{ }^{1} \mathrm{H}$ COSY experiment revealed that the methylene at $2.97 \mathrm{ppm}$ was coupled to the quartet at $2.44 \mathrm{ppm}$ which in turn was coupled to the pro- 
<smiles>CC(C)=CCCC(C)=CCCC(=O)c1c(C)cccc1O</smiles><smiles>[2H]C(C)=CCCC(C)=CCCC(=O)c1c(C)cccc1O</smiles><smiles>CC(C)=CCC(O)C(C)C=C(C)C</smiles><smiles>CC(C)(C)CCC(=O)CCC(C)(C)O</smiles><smiles>CC(C)=CCCC(O)(Br)C1Cc2c(c(=O)oc3cccc(C)c23)O1</smiles>

6

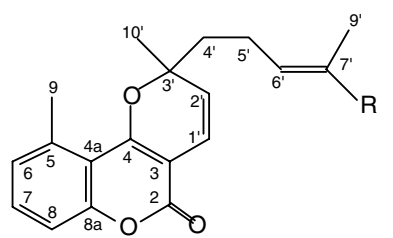

$7 \mathrm{R}=\mathrm{CH}_{3}$<smiles>CC(C)=CCC(O)C(C)C</smiles>

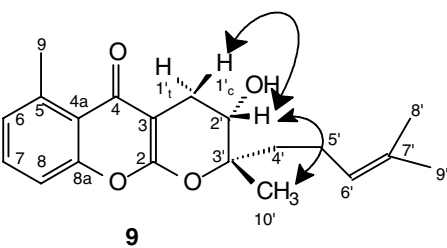

Fig. 1. Chemical Structures of mutisiphenones A (1), B (2), C (3), D (4) and E (5), mutisicoumarins A (6), B (7) and $\mathrm{C}(\mathbf{8})$ and mutisichromone (9).

ton at $5.13 \mathrm{ppm}$. This olefinic proton was coupled to the methyl signal at $1.63 \mathrm{ppm}$ while the olefinic signal at $5.07 \mathrm{ppm}$ was assigned to a terminal isobutenyl group on the basis of its coupling with the methyl signals at 1.59 and $1.67 \mathrm{ppm}$ in the ${ }^{1} \mathrm{H}-{ }^{1} \mathrm{H}$ COSY spectrum. The ${ }^{13} \mathrm{C}$ NMR and DEPT signals confirmed the presence of this group, with two methyl signals at 17.7 and $25.6 \mathrm{ppm}$ (Viturro et al., 2001). E geometry of the double bond between C-2' and C-3' was deduced from the upfield chemical shift of $\mathrm{C}-10^{\prime}$ and the downfield chemical shift of C-4' (Moreira et al., 1998).

Mutisiphenone B (2) was formulated as $\mathrm{C}_{24} \mathrm{H}_{34} \mathrm{O}_{3}$ from HRFABMS. The peak at $m / z 135$ in the EIMS of 2 and the hydroxyl (3600$\left.2600 \mathrm{~cm}^{-1}\right)$ and ketone $\left(1664 \mathrm{~cm}^{-1}\right)$ bands in its IR spectrum showed that compound $\mathbf{2}$ has the same trisubstituted aromatic skeleton as $\mathbf{1}$. This was confirmed by ${ }^{1} \mathrm{H}$ and ${ }^{13} \mathrm{C}$ NMR data (Tables I and II). The ${ }^{13} \mathrm{C}$ NMR spectrum with DEPT displayed signals due to five methyls, five methylenes, one oxomethine ( $\delta 74.2)$, six methines, one oxygen- bearing quaternary carbon ( $\delta$ 160.3), one carbonyl ( $\delta$ 208.5) and five quaternary carbons. These data suggested the presence of a monooxygenated farnesyl group attached to $\mathrm{C}-3$. The ${ }^{1} \mathrm{H}^{1}{ }^{1} \mathrm{H}$ COSY experiment revealed that the secondary hydroxyl proton $(\delta 3.96,1 \mathrm{H}, \mathrm{dd}, J=7.6 \mathrm{~Hz}$ and $J=5.6 \mathrm{~Hz})$ was coupled to the signals at 2.20 and $2.27 \mathrm{ppm}$ corresponding to the protons attached to C- $9^{\prime}$ as deduced from the crosspeaks $2.20 / 34.3$ and 2.27/ 34.3 in the HETCOR spectrum. Both protons were coupled to the signal at $5.09 \mathrm{ppm}$, which in turn was coupled to the methyl signals at 1.63 and $1.72 \mathrm{ppm}$ in the ${ }^{1} \mathrm{H}-{ }^{1} \mathrm{H}$ COSY spectrum. All proton and carbon signals of 2 could be assigned unambiguously from ${ }^{1} \mathrm{H}-{ }^{1} \mathrm{H}$ COSY, DEPT and HETCOR spectra.

Mutisiphenone $\mathrm{C}(\mathbf{3})$ was obtained as a colorless oil and formulated as $\mathrm{C}_{24} \mathrm{H}_{32} \mathrm{O}_{4}$ from HRFABMS. A close similarity of the ${ }^{13} \mathrm{C}$ NMR spectra (Table II) of $\mathbf{3}$ to that of $\mathbf{2}$ except for the presence of an additional carbonyl ( $\delta$ 201.4) and an olefinic carbon at $145.0 \mathrm{ppm}$ suggested an $\alpha, \beta$ unsaturated 
Table I. ${ }^{1} \mathrm{H}$ NMR spectral data for $\mathbf{1 - 4}\left(500 \mathrm{MHz}, \mathrm{CDCl}_{3}\right)$ and $5\left(200 \mathrm{MHz}, \mathrm{CDCl}_{3}\right)$.

\begin{tabular}{|c|c|c|c|c|c|}
\hline Position & $\begin{array}{l}\text { Compound } 1 \\
\delta_{\mathrm{H}}, J[\mathrm{~Hz}]\end{array}$ & $\begin{array}{c}\text { Compound } 2 \\
\delta_{\mathrm{H}}, J[\mathrm{~Hz}]\end{array}$ & $\begin{array}{l}\text { Compound } 3 \\
\delta_{\mathrm{H}}, J[\mathrm{~Hz}]\end{array}$ & $\begin{array}{c}\text { Compound } 4 \\
\delta_{\mathrm{H}}, J[\mathrm{~Hz}]\end{array}$ & $\begin{array}{c}\text { Compound } 5 \\
\delta_{\mathrm{H}}, J[\mathrm{~Hz}]\end{array}$ \\
\hline 3 & $2.97 t(7.3)$ & $2.97 t(7.3)$ & $2.96 t(7.3)$ & $2.97 t(7.3)$ & $2.97 t(7.3)$ \\
\hline 6 & $\begin{array}{l}6.72 d d c(8.4 \\
1.4,0.7)\end{array}$ & 6.71 brd (7.5) & $6.71 d q(7.5,0.5)$ & $\begin{array}{c}6.71 d d q(7.5,1.4 \\
0.7)\end{array}$ & $\begin{array}{c}6.71 d d q(7.7 \\
1.4,0.7)\end{array}$ \\
\hline 7 & $7.25 d d(8.4,7.5)$ & $7.24 d d(8.4,7.5)$ & $7.24 d d(8.4,7.5)$ & $7.23 d d(8.2,7.5)$ & $7.24 d d(8.0,7.7)$ \\
\hline 8 & 6.82 br dd $(7.5,1.4)$ & 6.81 br d (8.4) & 6.81 br $d(8.4)$ & $\begin{array}{c}6.80 \text { br dd }(8.2 \\
1.4)\end{array}$ & $\begin{array}{c}6.81 \mathrm{br} d d(8.0 \\
1.4)\end{array}$ \\
\hline 9 & $2.58 \mathrm{brs}$ & $2.57 \mathrm{brs}$ & $2.55 \mathrm{brs}$ & $2.53 \mathrm{brs}$ & $2.52 \mathrm{brs}$ \\
\hline $1^{\prime}$ & $2.44 q(7.3)$ & $2.43 q(7.3)$ & $2.43 q(7.3)$ & $2.43 q(7.3)$ & $2.44 q(7.3)$ \\
\hline $2^{\prime}$ & $5.13 \operatorname{tq}(7.3,1.4)$ & $5.14 \operatorname{tq}(7.3,1.4)$ & $5.15 \operatorname{tq}(7.3,1.4)$ & $5.17 \operatorname{tq}(7.3,1.4)$ & 5.18 brt $(7.3)$ \\
\hline $4^{\prime}$ & 1.97 brt $(7.3)$ & $2.02 \mathrm{~m}$ & 2.09 brt $(7.0)$ & 2.13 brt $(7.3)$ & 2.15 brt $(7.0)$ \\
\hline $5^{\prime}$ & $2.06 \mathrm{br} d t(6.8,7.3)$ & $2.12 \mathrm{~m}, 2.09 \mathrm{~m}$ & $2.33 q(7.0)$ & $2.35 d t(7.1,7.3)$ & $2.37 \mathrm{~m}$ \\
\hline $6^{\prime}$ & $5.07 \operatorname{tq}(6.8,1.4)$ & 5.36 br t (6.8) & $6.55 \operatorname{tq}(7.0,1.4)$ & $6.62 \operatorname{tq}(7.1,1.4)$ & 6.61 brt $(7.0)$ \\
\hline $8^{\prime}$ & $1.67 d(1.4)$ & $3.96 d d(7.6,5.6)$ & - & - & - \\
\hline $9^{\prime}$ & $1.59 \mathrm{br} s$ & $2.20 \mathrm{~m}, 2.27 \mathrm{~m}$ & $5.28 d(9.8)$ & 2.57 brt $(6.0)$ & $2.73 \mathrm{~m}$ \\
\hline $10^{\prime}$ & $1.63 \mathrm{brs}$ & $5.09 t q(7.2,1.4)$ & $4.99 d q(9.8,1.4)$ & $1.74 \mathrm{~m}$ & $1.80 \mathrm{~m}$ \\
\hline $12^{\prime}$ & & $1.72 \mathrm{brs}$ & $1.74 d(1.4)$ & $1.37 \mathrm{~s}$ & $1.38 s$ \\
\hline $13^{\prime}$ & & $1.63 \mathrm{brs}$ & $1.84 d(1.4)$ & $1.37 \mathrm{~s}$ & $1.38 \mathrm{~s}$ \\
\hline $14^{\prime}$ & & 1.63 br s & $1.81 d(1.4)$ & $1.83 d(1.4)$ & $1.83 d(1.4)$ \\
\hline $15^{\prime}$ & & $1.61 \mathrm{brs}$ & $1.64 \mathrm{brs}$ & $1.64 d(1.4)$ & $1.64 \mathrm{brs}$ \\
\hline $8 \mathrm{a} \mathrm{OH}$ & $11.59 \mathrm{brs}$ & $11.45 \mathrm{brs}$ & $11.41 \mathrm{brs}$ & $11.41 \mathrm{brs}$ & $11.41 \mathrm{brs}$ \\
\hline $8^{\prime} \mathrm{OH}$ & & $3.49 \mathrm{brs}$ & & & \\
\hline $9^{\prime} \mathrm{OH}$ & & & $3.96 \mathrm{brs}$ & & \\
\hline $11^{\prime} \mathrm{OOH}$ & & & & & $6.86 s$ \\
\hline
\end{tabular}

Table II. ${ }^{13} \mathrm{C}$ NMR spectral data for $\mathbf{1 - 4}, \mathbf{6}$ and $9\left(125 \mathrm{MHz}, \mathrm{CDCl}_{3}\right)$.

\begin{tabular}{|c|c|c|c|c|c|c|}
\hline Position & $\underset{\delta_{C}}{\text { Compound } 1}$ & $\underset{\delta_{C}}{\text { Compound } 2}$ & $\begin{array}{c}\text { Compound } \mathbf{3} \\
\delta_{C}\end{array}$ & $\underset{\delta_{C}}{\text { Compound } 4}$ & $\underset{\delta_{C}}{\text { Compound } 6}$ & $\underset{\delta_{C}}{\text { Compound } 9}$ \\
\hline 2 & & & & & 160.5 & 160.9 \\
\hline 3 & 44.6 & 44.5 & 44.3 & 44.4 & 102.9 & 93.3 \\
\hline 4 & 208.6 & 208.5 & 208.2 & 208.2 & 167.7 & 180.3 \\
\hline $4 a$ & 122.5 & 120.2 & 121.2 & 120.8 & 111.8 & 120.6 \\
\hline 5 & 138.6 & 138.5 & 138.4 & 138.4 & 135.8 & 140.8 \\
\hline 6 & 122.4 & 122.7 & 123.1 & 123.1 & 126.3 & 127.8 \\
\hline 7 & 134.0 & 133.9 & 133.9 & 133.7 & 131.6 & 131.7 \\
\hline 8 & 116.3 & 116.2 & 116.2 & 116.1 & 115.0 & 115.3 \\
\hline $8 \mathrm{a}$ & 161.6 & 160.3 & 161.2 & 162.0 & 155.9 & 154.8 \\
\hline 9 & 24.2 & 25.0 & 23.9 & 23.7 & 21.3 & 22.5 \\
\hline $1^{\prime}$ & 23.4 & 23.4 & 23.3 & 23.3 & 26.9 & 24.8 \\
\hline $2^{\prime}$ & 123.1 & 123.1 & 123.7 & 123.6 & 92.1 & 67.4 \\
\hline $3^{\prime}$ & 136.8 & 136.8 & 137.9 & 138.0 & 73.6 & 85.5 \\
\hline $4^{\prime}$ & 39.7 & 39.2 & 38.1 & 38.2 & 37.4 & 37.2 \\
\hline $5^{\prime}$ & 26.6 & 26.0 & 27.4 & 27.4 & 22.0 & 21.6 \\
\hline $6^{\prime}$ & 124.2 & 125.8 & 145.0 & 142.8 & 123.7 & 123.2 \\
\hline $7^{\prime}$ & 131.4 & 134.7 & 135.2 & 135.4 & 132.7 & 132.7 \\
\hline $8^{\prime}$ & 25.6 & 74.2 & 201.4 & 197.0 & 25.7 & 25.6 \\
\hline $9^{\prime}$ & 17.7 & 34.3 & 69.8 & 46.1 & 17.7 & 17.7 \\
\hline $10^{\prime}$ & 16.0 & 122.9 & 123.5 & 26.2 & 22.7 & 18.8 \\
\hline $11^{\prime}$ & & 136.4 & 133.9 & 71.6 & & \\
\hline $12^{\prime}$ & & 25.9 & 25.9 & 29.5 & & \\
\hline $13^{\prime}$ & & 18.0 & 18.4 & 29.5 & & \\
\hline $14^{\prime}$ & & 11.7 & 11.8 & 11.8 & & \\
\hline $15^{\prime}$ & & 16.0 & 15.9 & 15.9 & & \\
\hline
\end{tabular}


ketone in the side chain. The ${ }^{1} \mathrm{H}$ NMR spectrum (Table I) showed a deshielded signal $(\delta 6.55)$ that was consistent with an olefinic proton of an enone (Amico et al., 1987). In the ${ }^{1} \mathrm{H}-{ }^{1} \mathrm{H}$ COSY spectrum the signal at $6.55 \mathrm{ppm}$ was coupled to the methyl group at $1.81 \mathrm{ppm}$ and the methylene protons at $2.33 \mathrm{ppm}$, which in turn were coupled to the methylene protons at $2.09 \mathrm{ppm}$. The HETCOR experiment showed that the oxomethine carbon $(\delta 69.8)$ correlated with the doublet $(J=9.8 \mathrm{~Hz})$ at $5.28 \mathrm{ppm}$. This proton was coupled to the olefinic proton at $4.99 \mathrm{ppm}$, which in turn was coupled to the vinylic methyls ( $\delta 1.74$ and 1.84) in the ${ }^{1} \mathrm{H}-{ }^{1} \mathrm{H}$ COSY spectrum. These observations indicated the position of the hydroxyl group at C-9'. The stereochemistry of the dioxygenated farnesyl group was assigned as $2^{\prime} E, 6^{\prime} E$ on the basis of the upfield chemical shifts of the vinylic methyls ( $\delta 11.8$ and 15.9) in the ${ }^{13} \mathrm{C}$ NMR spectrum of 3 (Breitmaier and Voelter, 1987).

The FABMS (negative ion mode) of Mutisiphenone D (4) exhibited a pseudomolecular ion peak at $m / z \quad 385[\mathrm{M}-\mathrm{H}]^{-}$which differed in two mass units of that of $\mathbf{3}$. Compound 4 showed similar ${ }^{1} \mathrm{H}$ and ${ }^{13} \mathrm{C}$ NMR spectra (Tables I and II) to that of 3 except for the absence of the isopentenyl hydroxylated terminal group signals. The absence of the signals at 5.28 and $4.99 \mathrm{ppm}$ in the ${ }^{1} \mathrm{H}$ NMR spectrum and presence of the quaternary signals at 71.6 and $197.0 \mathrm{ppm}$ in the ${ }^{13} \mathrm{C}$ NMR spectrum indicated that the hydroxyl group was not vicinal to the carbonyl. The presence of a singlet at $1.37 \mathrm{ppm}(6 \mathrm{H})$ confirmed the position of the hydroxyl group at C-11' (Loyola et al., 1985). Compound $\mathbf{4}$ decomposed in chloroformic solution as observed by TLC.

Mutisiphenone E (5) showed a pseudomolecular ion at $m / z 401$ [M-H $^{-}$in the FABMS (negative ion mode) which differed in sixteen mass units of that of 4. The ${ }^{1} \mathrm{H}$ NMR spectra (Table I) of both compounds were practically superimposable except for the presence of a broad singlet at $6.86 \mathrm{ppm}$ in $\mathbf{5}$ suggesting the presence of a hydroperoxide proton (Appendino et al., 1983) in accordance with the difference observed in the mass spectra of compounds 4 and 5. Both compounds differed in their retention times in reversed-phase HPLC and in their $R_{f}$ values in reversed-phase TLC.

The known Mutisicoumarin A (6) was identified by comparison of EIMS and ${ }^{1} \mathrm{H}$ NMR data (see
Experimental) with published results (Zdero et al., 1986) and by ${ }^{13} \mathrm{C}$ NMR, DEPT and HETCOR experiments that allowed for the first time the unambiguous assignment of all carbon signals (Table II). 2D NOESY data allowed us to determine the stereochemistry at $\mathrm{C}-2^{\prime}$ relative to diastereotopic protons at $\mathrm{C}-1^{\prime}$, indicating that $\mathrm{H}-2^{\prime}$ and $H-1^{\prime}$ ( $\left.\delta 3.08\right)$ are on the same side of the molecule.

Mutisicoumarin B (7) was obtained as a colorless oil. Its ${ }^{1} \mathrm{H}$ NMR spectrum (Table III) showed signals for three aromatic protons at 7.01, 7.16 and $7.34 \mathrm{ppm}$ and a broadened methyl singlet at $2.73 \mathrm{ppm}$, characteristic for a 5-methylcoumarin (Bohlmann and Zdero, 1977). The presence of an isolated olefinic $\mathrm{AB}$ system as a pair of doublets $(J=10 \mathrm{~Hz})$ at 5.42 and $6.59 \mathrm{ppm}$ and an allylic methyl group attached to an olefinic carbon at 1.53 ppm was consistent with the presence of a pyrano [3,2-c] coumarin moiety as for ferprenin, a prenylated coumarin isolated from Ferula communis (Appendino et al., 1988). In the EIMS, the molecular ion peak at $\mathrm{m} / \mathrm{z} 310$ and the strong fragment ion at $m / z 227$, resulting from allylic cleavage between C-3' and C-4' with the loss of a $\mathrm{C}_{6} \mathrm{H}_{11}$ unit, were consistent with the molecular formula $\mathrm{C}_{20} \mathrm{H}_{22} \mathrm{O}_{3}$. These data together with the presence in the ${ }^{1} \mathrm{H}$ NMR spectrum of an olefinic proton at $\delta 5.10$, two methylene multiplets at $\delta 1.93$ and 2.15 and two methyl groups attached to an olefinic carbon $\left(\mathrm{C}-8^{\prime}, \delta 1.62\right.$ and $\left.\mathrm{C}-9^{\prime}, \delta 1.56\right)$ confirmed the presence of a $\mathrm{CH}_{2} \mathrm{CH}_{2} \mathrm{CH}=\mathrm{C}\left(\mathrm{CH}_{3}\right)_{2}$ unit attached to $\mathrm{C}-3^{\prime}$. The ${ }^{13} \mathrm{C}$ NMR spectrum of 7 could not be recorded due to its unstability in chloroformic solution, as observed for ferprenin (Appendino et al., 1988).

Mutisicoumarin C (8) was isolated as an optically active colourless oil. The ${ }^{1} \mathrm{H}$ NMR spectrum of $\mathbf{8}$ (Table III) exhibited characteristic signals for the pyrano $[3,2-c]$ coumarin moiety. The EIMS showed a fragment ion peak at $m / z 376\left[\mathrm{M}-\mathrm{H}_{2} \mathrm{O}\right]$ and the typical strong fragment ion at $m / z, 227$ due to the allylic cleavage between C-3' and C-4'. These data confirmed that compounds $\mathbf{7}$ and $\mathbf{8}$ differed only in the side chain. The presence of an hydroxyl group in $\mathbf{8}$ was deduced from the band at $3430 \mathrm{~cm}^{-1}$ in the IR spectrum and by the signal for a methine proton attached to an oxygenated carbon ( $\delta 3.95)$ in the ${ }^{1} \mathrm{H}$ NMR spectrum. The position of the hydroxyl group at C-8' was deduced 


\begin{tabular}{|c|c|c|c|}
\hline Position & $\begin{array}{c}\text { Compound } 7 \\
\delta_{\mathrm{H}}, J[\mathrm{~Hz}]\end{array}$ & $\begin{array}{c}\text { Compound } 8 \\
\delta_{\mathrm{H}}, J[\mathrm{~Hz}]\end{array}$ & $\begin{array}{c}\text { Compound } 9 \\
\delta_{\mathrm{H}}, J[\mathrm{~Hz}]\end{array}$ \\
\hline 6 & $7.01 \mathrm{brd}(7.6)$ & $7.02 d$ ancho (7.3) & $7.10 d q(7.1,1.2)$ \\
\hline 7 & 7.34 br dd $(8.0,7.6)$ & $7.35 d d(7.7,7.3)$ & 7.41 br dd $(7.7,7.1)$ \\
\hline 8 & 7.16 br d (8.0) & 7.15 br d (7.7) & 7.21 br d (7.7) \\
\hline 9 & $2.73 \mathrm{brs}$ & $2.73 \mathrm{brs}$ & $2.87 \mathrm{brs}$ \\
\hline $1^{\prime}$ & $6.59 d(10.0)$ & $6.60 d(10.2)$ & $\begin{array}{rl}\mathrm{H}_{\mathrm{c}} & 2.89 d d(16.5,5.0)^{\mathrm{a}} \mathrm{H}_{\mathrm{t}} \\
& 2.62 d d(16.5,6.0)^{\mathrm{a}}\end{array}$ \\
\hline $2^{\prime}$ & $5.42 d(10.0)$ & $5.43 d(10.2)$ & $3.96 d d(6.0,5.0)$ \\
\hline $4^{\prime}$ & $1.93 \mathrm{~m}$ & $1.99 \mathrm{~m}$ & $1.74 \mathrm{~m}, 1.66 \mathrm{~m}$ \\
\hline $5^{\prime}$ & $2.15 \mathrm{~m}$ & 2.22 brt $(7.3)$ & $2.19 m, 2.17 m$ \\
\hline $6^{\prime}$ & $5.10 \mathrm{tq}(7.1,1.4)$ & 5.41 brt (7.3)) & $5.09 \operatorname{tq}(7.1,1.4)$ \\
\hline $8^{\prime}$ & $1.62 d(1.4)$ & 3.95 brt (7.3) & $1.67 \mathrm{brs}$ \\
\hline $9^{\prime}$ & $1.56 \mathrm{brs}$ & 2.22 brtt(7.3) & $1.61 \mathrm{brs}$ \\
\hline $10^{\prime}$ & $1.53 s$ & 5.07 brt (7.3) & $1.45 s$ \\
\hline $12^{\prime}$ & & $1.71 \mathrm{brs}$ & \\
\hline $13^{\prime}$ & & $1.63 \mathrm{brs}$ & \\
\hline $14^{\prime}$ & & $1.60 \mathrm{brs}$ & \\
\hline $15^{\prime}$ & & $1.55 s$ & \\
\hline
\end{tabular}

Table III. ${ }^{1} \mathrm{H} \quad$ NMR spectral data for $\mathbf{7}$ and $\mathbf{9}$ $\left(500 \mathrm{MHz}, \mathrm{CDCl}_{3}\right)$ and $\mathbf{8}$ $\left(200 \mathrm{MHz}, \mathrm{CDCl}_{3}\right.$ ).

a Cis and trans refer to $\mathrm{H}-2^{\prime}$. by comparison of the ${ }^{1} \mathrm{H}$ NMR data of $\mathbf{8}$ with that of 2 , which showed the same terminal rest in the side chain. The presence of two olefinic proton signals as triplets $\left(\mathrm{H}-6^{\prime}, \delta 5.41\right.$ and $\mathrm{H}-10^{\prime}, \delta$ 5.07) indicated that each olefinic proton was adjacent to one methylene group. The coupling pattern of the hydroxymethine proton $(b r t, J=7.3 \mathrm{~Hz})$ confirmed the position of the hydroxyl at C-8'.

Mutisichromone (9) was obtained as an optically active colorless oil. The HRMS of 9 was consistent with a $\mathrm{C}_{20} \mathrm{H}_{22} \mathrm{O}_{3}$ formula. The IR spectrum showed characteristic bands at 1650, 1630 and $1570 \mathrm{~cm}^{-1}$ for a chromone nucleus (Murray et al., 1982). The presence of the RDA ion fragment at $m / z 188$ in the EIMS of 9 also supported this structure. The ${ }^{1} \mathrm{H}$ NMR spectrum (Table III) showed signals at $\delta 7.10(1 \mathrm{H}, d q, J=7.1 \mathrm{~Hz}$ and $J=$ $1.2 \mathrm{~Hz}), 7.21(1 \mathrm{H}, \mathrm{br} d, J=7.7 \mathrm{~Hz})$ and $7.41(1 \mathrm{H}$ br $d d, J=7.7 \mathrm{~Hz}$ and $J=7.1 \mathrm{~Hz}$ ), characteristic of a 1,2,3-trisubstituted aromatic ring. The presence of a broad methyl singlet at 2.87 ppm indicated a 5-methylchromone (Bittner et al., 1988). The ${ }^{13} \mathrm{C}$ NMR spectrum (Table II) with DEPT displayed signals due to one methylene ( $\delta 24.8)$, one oxygenated methine ( $\delta$ 67.4) and one oxygen-bearing quaternary carbon $\left(\delta\right.$ 85.5). The ${ }^{1} \mathrm{H}-{ }^{1} \mathrm{H}$ COSY spectrum showed that the secondary hydroxyl proton $(\delta 3.96,1 \mathrm{H}, d d, J=6.0 \mathrm{~Hz}$ and $J=5.0 \mathrm{~Hz}$ ) was coupled with protons at 2.62 and $2.89 \mathrm{ppm}$, which correlated in the HETCOR spectrum with the signal at $24.8 \mathrm{ppm}$. These data suggested the presence of a $2^{\prime}$-hydroxy-2,3-dihydropyranochromone. The fragment ion peaks at $m / z 83$ and $227\left[\mathrm{M}-\mathrm{H}_{2} \mathrm{O}\right.$ $-83]^{+}$in the EIMS of 9 were consistent with the presence of a methyl and a $4^{\prime}$-methyl-3'-pentenyl chain attached to $\mathrm{C}-3^{\prime}$. This was confirmed by the methyl singlet at $1.45 \mathrm{ppm}$ in the ${ }^{1} \mathrm{H}$ NMR spectrum together with the vinylic methyls at 1.61 and 1.67 ppm. ${ }^{1} \mathrm{H}-{ }^{1} \mathrm{H}$ COSY and HETCOR crosspeaks were in good agreement with the proposed structure. The relative configurations at C-2' and C-3' were assigned on the basis of the 2D NOESY spectrum, which exhibited NOE's, indicating that Me-10', H-2' and H-1' ( $\delta$ 2.89) are on the same side of the molecule, while the hydroxyl group has the same orientation as the $4^{\prime}$-methyl-3'-pentenyl chain (Fig. 1).

Compounds 1, 2, 4 and 6 were evaluated by a bioautographic technique (Homans and Fuchs, 1970) for their antifungal activity against the plant pathogenic fungus Cladosporium cucumerinum. Compounds 1, 4 and $\mathbf{6}$ showed inhibition zones of 12, 11 and $14 \mathrm{~mm}$, respectively, at a concentration of $100 \mu \mathrm{g} / \mathrm{spot}(0.26-0.35 \mu \mathrm{mol} / \mathrm{spot})$. The compounds were found to be less active than benomyl, a commercially available fungicide, which showed an inhibition zone of $20 \mathrm{~mm}$ at a concentration of $10 \mu \mathrm{g} / \mathrm{spot}$. Mutisiphenone B (2) was inactive at the concentration tested.

Terpenylacetophenones $\mathbf{1 - 5}$ and chromone $\mathbf{9}$ are described for the first time in the genus Mutisia. These type of compounds together with 5- 
methylcoumarins are not widespread in nature but have been reported in species of the subtribes Mutisiinae (Zdero et al., 1986, 1988; Torrado Truiti and Sarragiotto, 1997), Nassauviinae (Hoeneisen et al., 1999; Bittner et al., 1994; Pritschow et al., 1991) and Gochnatiinae (Bohlmann et al., 1985; Zdero et al., 1988) in the tribe Mutisieae and in a few species of the tribe Vernonieae (Mahmoud et al., 1998; Jakupovic et al., 1987). These compounds may have chemotaxonomic relevance for the tribe Mutisieae.

\section{Experimental}

\section{General methods}

${ }^{1} \mathrm{H}$ and ${ }^{13} \mathrm{C}$ NMR spectra were recorded in $\mathrm{CDCl}_{3}$ on a Bruker ACE-200 and AM 500 spectrometers. Carbon substitution degrees in ${ }^{13} \mathrm{C}$ NMR spectra were established by DEPT multiple sequence. Mass spectra were measured on a TRIO-2 VG mass spectrometer. IR spectra were obtained on an IRFT Bruker IFS 88 spectrometer. Optical rotations were determined on a PerkinElmer 343 polarimeter. Preparative HPLC was carried out on an SP liquid chromatograph equipped with a Spectra Series P100 solvent delivery system, a Rheodyne manual injector and a refractive index detector using a YMC-Pack ODS-A $5 \mu$ column $(25 \mathrm{~cm} \times 20 \mathrm{~mm}$ i.d. $)$. TLC was performed on precoated silica gel $60 \mathrm{~F}_{254}$ (cyclohexaneEtOAc (6:4)) and ODS reversed-phase plates $\left(80 \% \mathrm{MeOH}-\mathrm{H}_{2} \mathrm{O}\right)$.

\section{Plant material}

Aerial parts of $M$. friesiana were collected in Jujuy, Departmento de Humahuaca, Argentina at $3500 \mathrm{~m}$ altitude in summer. The species was identified by Ing. Novara of the Facultad de Ciencias Naturales, Universidad de Salta. A voucher specimen is deposited at the Herbarium of the Facultad de Ciencias Naturales, Universidad de Salta under the number H. G. 1064.

\section{Extraction and isolation}

Cut dried and powdered plant material (550 g) was extracted with $\mathrm{MeOH}(3 \times 1.51)$ at room temperature. The $\mathrm{MeOH}$ extracts were concentrated in vaccum to give a residue $(100 \mathrm{~g})$ which was partitioned with $n$-hexane-MeOH/ $\mathrm{H}_{2} \mathrm{O}(10: 3: 1 \mathrm{v} / \mathrm{v} / \mathrm{v})$, yielding a non-polar and an aqueous phase. The polar phase was extracted with $\mathrm{CHCl}_{3}$. The extract was evaporated to dryness to yield a chloroform residue $(10 \mathrm{~g})$. Part of this residue $(3 \mathrm{~g})$ was subjected to vacuum dry-column chromatography on silica gel $60 \mathrm{H}$, eluting with cyclohexane, EtOAc, acetone and $\mathrm{MeOH}$ to give ten fractions. Fraction 3 (1.114 mg) was subjected to vaccum dry-column on RP-18 with $\mathrm{H}_{2} \mathrm{O} / \mathrm{MeOH}(7: 3 ; 6: 4 ; 5: 5 ; 4: 6 ; 3: 7$; $2: 8 ; 1: 10 \mathrm{v} / \mathrm{v}), \mathrm{MeOH}$ and acetone to give 9 fractions $(3.1-3.9)$. Fractions $3.4(240 \mathrm{mg})$ and 3.5 (128 mg) were submitted to repeated reversedphase HPLC (ODS, $\mathrm{MeOH} / \mathrm{H}_{2} \mathrm{O}(8: 2 \mathrm{v} / \mathrm{v})$, flow rate $6 \mathrm{ml} / \mathrm{min}$ ) to give methylphenones $\mathbf{3}(7 \mathrm{mg})$ and 4 (3 $\mathrm{mg}$ ) from fraction 3.4 and methylphenone 2 (4 mg) and mutisicoumarin A (6,11 mg) from fraction 3.5. Fraction $3.6(110 \mathrm{mg})$ was purified by flash cromatography on silica gel $\mathrm{H}(10-40 \mu \mathrm{m})$, eluting with mixtures of increasing polarity of cyclohexane, EtOAc, acetone and $\mathrm{MeOH}$ to give 28 fractions (3.6.1-3.6.28). Fractions 3.6.23 and 3.6.24 were pooled $(68 \mathrm{mg})$ and purified by reversedphase HPLC (ODS, $\mathrm{MeOH} / \mathrm{H}_{2} \mathrm{O}(8: 2 \mathrm{v} / \mathrm{v})$, flow rate $6 \mathrm{ml} / \mathrm{min}$ ) to give mutisicoumarin $A$ (6) (7 mg) and compounds $\mathbf{1}(2 \mathrm{mg})$ and $\mathbf{8}(1.4 \mathrm{mg})$. Fractions 3.6.27 and 3.6.28 (30 mg) were subjected to reversed-phase HPLC (ODS, $\mathrm{MeOH} / \mathrm{H}_{2} \mathrm{O}(8: 2$ $\mathrm{v} / \mathrm{v})$, flow rate $6 \mathrm{ml} / \mathrm{min}$ ) to afford compound 5 $(1.7 \mathrm{mg})$. Fraction 3.7 (150 mg) was submitted to reversed-phase HPLC (ODS, $\mathrm{MeOH} / \mathrm{H}_{2} \mathrm{O}$ (95:5 $\mathrm{v} / \mathrm{v}$ ), flow rate $6 \mathrm{ml} / \mathrm{min}$ ) to give 10 fractions (3.7.1-3.7.10). Purification of fractions 3.7.6 $(10 \mathrm{mg})$ and $3.7 .8(7 \mathrm{mg})$ by preparative TLC (silica gel $\mathrm{G}, \mathrm{F}_{254}$, cyclohexane/EtOAC (6:4 v/v)) afforded compounds $\mathbf{1}(2 \mathrm{mg}), \mathbf{7}(2 \mathrm{mg})$ and 9 (2 mg).

\section{1-(2-Hydroxy-6-methylphenyl)-5,9-dimethyl-4,8- decadien-1-one (1)}

Colorless oil, $[\alpha]_{\mathrm{D}}-25.5^{\circ}\left(c 0.25, \mathrm{CHCl}_{3}\right)$; UV $(\mathrm{MeOH}) \lambda_{\max } \mathrm{nm}(\log \varepsilon) 289$ (3.1), 247 (3.3), 203 (4.2); IR (KBr) $v_{\max } 3600-2600,1665,1626,1604$, 1580, 1464, 1266, $777 \mathrm{~cm}^{-1} ;{ }^{1} \mathrm{H}$ and ${ }^{13} \mathrm{C}$ NMR see Tables I and II; EIMS $m / z$ (rel. int.): $286[\mathrm{M}]^{+}(2)$, 217 (4), 219 (7), 150 (4), 147 (2), 135 (100), 69 (30), 41 (86); FABMS (positive ion mode) $m / z 287$ $[\mathrm{M}+\mathrm{H}]^{+}(90), 135$ (100); FABMS (negative ion mode) $m / z 285[\mathrm{M}-\mathrm{H}]^{-}$(100); HREIMS $m / z[\mathrm{M}]^{+}$: calcd. for $\mathrm{C}_{19} \mathrm{H}_{26} \mathrm{O}_{2}, 286.1933$; found, 286.1939. 
5,9,13-Trimethyl-10-hydroxy-1-(2-hydroxy-6methylphenyl)-4,8,12-tetradecatrien-1-one (2)

Colorless oil, IR (KBr) $v_{\max } 3600-2600,1666$, 1626, 1604, 1580, 1464, 1266, $777 \mathrm{~cm}^{-1} ;{ }^{1} \mathrm{H}$ and ${ }^{13} \mathrm{C}$ NMR see Tables I and II; FABMS (positive ion mode) $m / z, 371[\mathrm{M}+\mathrm{H}]^{+}(1), 353\left[\mathrm{M}-\mathrm{H}_{2} \mathrm{O}+\mathrm{H}\right]^{+}$ (10), 135 (100); FABMS (negative ion mode) $\mathrm{m} / \mathrm{z}$

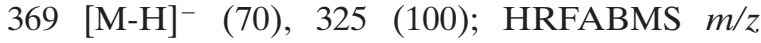
$[\mathrm{M}+\mathrm{H}]^{+}$: calcd. for $\mathrm{C}_{24} \mathrm{H}_{35} \mathrm{O}_{3}, 371.2587$; found, 371.2595 .

5,9,13-Trimethyl-11-hydroxy-1-(2-hydroxy-6methylphenyl)-4,8,12-tetradecatrien-1,10-dione (3)

Colorless oil, $[\alpha]_{\mathrm{D}}-30.6^{\circ}\left(c 0.16, \mathrm{CHCl}_{3}\right)$; IR $(\mathrm{KBr}) v_{\max } 3600-2600,1664,1604,1580,1464$, 1217, 1266, 1038, $773 \mathrm{~cm}^{-1} ;{ }^{1} \mathrm{H}$ and ${ }^{13} \mathrm{C}$ NMR see Tables I and II; FABMS (positive ion mode) $\mathrm{m} / \mathrm{z}$ $385[\mathrm{M}+\mathrm{H}]^{+}(1), 367\left[\mathrm{M}-\mathrm{H}_{2} \mathrm{O}+\mathrm{H}\right]^{+}(8), 135$ (100); FABMS (negative ion mode) $\mathrm{m} / z \quad 383[\mathrm{M}-\mathrm{H}]^{-}$ (30), 149 (100); HRFABMS $\mathrm{m} / z[\mathrm{M}+\mathrm{H}]^{+}$: calcd. for $\mathrm{C}_{24} \mathrm{H}_{33} \mathrm{O}_{4}, 385.2379$; found, 385.2389 .

5,9,13-Trimethyl-13-hydroxy-1-(2-hydroxy-6methylphenyl)-4,8-tetradecadien-1,10-dione (4)

Colorless oil, ${ }^{1} \mathrm{H}$ and ${ }^{13} \mathrm{C}$ NMR see Tables I and II; FABMS (positive ion mode) $\mathrm{m} / z 387[\mathrm{M}+\mathrm{H}]^{+}$ (1), $369\left[\mathrm{M}-\mathrm{H}_{2} \mathrm{O}+\mathrm{H}\right]^{+}$(43), 367 (50), 135 (100); FABMS (negative ion mode) $m / z, 385[\mathrm{M}-\mathrm{H}]^{-}(30)$, HRFABMS $m / z$, [M-H $]^{-}$: calcd. for $\mathrm{C}_{24} \mathrm{H}_{33} \mathrm{O}_{4}$, 385.2379; found, 385.2393 .

5,9,13-Trimethyl-13-hydroperoxy-1-(2-hydroxy-6methylphenyl)-4,8-tetradecadien-1,10-dione (5)

Colorless oil, ${ }^{1} \mathrm{H}$ and ${ }^{13} \mathrm{C}$ NMR see Tables I and II; FABMS (positive ion mode) $\mathrm{m} / z \quad 369$ $\left[\mathrm{M}-\mathrm{H}_{2} \mathrm{O}+\mathrm{H}\right]^{+}(5), 135$ (100); FABMS (negative ion mode) $m / z$ $401[\mathrm{M}-\mathrm{H}]^{-}$(20), HRFABMS $\mathrm{m} / \mathrm{z}$ $[\mathrm{M}-\mathrm{H}]^{-}$: calcd. for $\mathrm{C}_{24} \mathrm{H}_{33} \mathrm{O}_{5}, 401.2328$; found, 401.2336.

\section{Mutisicoumarin A (6)}

Colourless solid, $[\alpha]_{\mathrm{D}}-10^{\circ}\left(c 0.40, \mathrm{CHCl}_{3}\right)$; UV $(\mathrm{MeOH}) \lambda_{\max } \mathrm{nm}(\log \varepsilon) 328$ (3.6), 314 (3.7), 299 (3.8), 285 (3.7), 240 (sh), 207 (5.5); IR (KBr) $v_{\max }$ 3600, 1699, 1631, 1604, 1570, 1464, 1390, 1149, 1032, 918, $756 \mathrm{~cm}^{-1} ;{ }^{1} \mathrm{H}$ NMR $\left(\mathrm{CDCl}_{3}, 500 \mathrm{MHz}\right)$ $\delta 1.36\left(3 \mathrm{H}, s, \mathrm{H}-10^{\prime}\right), 1.60\left(2 \mathrm{H}, m, \mathrm{H}-4^{\prime}\right), 1.64(3 \mathrm{H}$, br s, H-9'), 1.70 (3H, br s, H-9'), $2.12(1 \mathrm{H}, b r d t$,
$\left.J=15 \mathrm{~Hz}, J=7 \mathrm{~Hz}, \mathrm{H}-5^{\prime}\right), 2.19(1 \mathrm{H}, b r d t, J=$ $\left.15 \mathrm{~Hz}, J=7 \mathrm{~Hz}, \mathrm{H}-5^{\prime}\right), 2.68$ (3H, br s, H-9), 3.08 $\left(1 \mathrm{H}, d d, J=15 \mathrm{~Hz}, J=10.4 \mathrm{~Hz}, \mathrm{H}-1^{\prime}\right), 3.15(1 \mathrm{H}$, $\left.d d, J=15 \mathrm{~Hz}, J=8.5 \mathrm{~Hz}, \mathrm{H}-1^{\prime}\right), 4.94(1 \mathrm{H}, d d, J=$ $\left.10.4 \mathrm{~Hz}, J=8.8 \mathrm{~Hz}, \mathrm{H}-2^{\prime}\right), 5.14(1 \mathrm{H}, t q, J=7.1 \mathrm{~Hz}$, $\left.J=1.4 \mathrm{~Hz}, \mathrm{H}-6^{\prime}\right), 7.04(1 \mathrm{H}, d q, J=7.3 \mathrm{~Hz}, J=$ $0.9 \mathrm{~Hz}, \mathrm{H}-6), 7.20(1 \mathrm{H}, b r d, J=8.4 \mathrm{~Hz}, \mathrm{H}-8), 7.38$ $(1 \mathrm{H}, b r d d, J=8.4 \mathrm{~Hz}, J=7.3 \mathrm{~Hz}, \mathrm{H}-7) ;{ }^{13} \mathrm{C}$ NMR see Table II; EIMS $m / z$ (rel. int.): $328\left[\mathrm{M}^{+}\right]$(2), 313 (1), 310 (1), 243 (5), 227 (10), 201 (16), 135 (42), 69 (28), 109 (11), 43 (100).

\section{2,10-Dimethyl-2-(4-methyl-3-pentenyl)-2H,5H- pyran [3,2-c] [1] benzopyran-5-one (7)}

Colorless oil, $[\alpha]_{\mathrm{D}}-33^{\circ}\left(c 0.14, \mathrm{CHCl}_{3}\right)$; UV $(\mathrm{MeOH}) \lambda_{\max }(\log \varepsilon) 370(\mathrm{sh}), 350$ (3.5), 295 (3.5), 251 (3.8), 209 (4.4) nm; IR (KBr) $v_{\max } 1710,1640$, 1610, 1570, 1460, 1370, 910, $760 \mathrm{~cm}^{-1} ;{ }^{1} \mathrm{H}$ NMR see Table III; EIMS $m / z$ (rel. int.): $310[\mathrm{M}]^{+}(7)$, $267[\mathrm{M}-\mathrm{Me}-\mathrm{CO}]^{+}(5), 227 \quad\left[\mathrm{M}-\left(\mathrm{CH}_{2}\right)_{2} \mathrm{CH}=\right.$ $\left.\mathrm{C}(\mathrm{Me})_{2}\right]^{+}$(67), 135 (19), 107 (15), 83 (7), 69 (90), 41 (100); HREIMS $m / z[\mathrm{M}]^{+}$: calcd. for $\mathrm{C}_{20} \mathrm{H}_{22} \mathrm{O}_{3}$, 310.1569; found, 310.1577 .

\section{2,10-Dimethyl-2-(5-hydroxy-4,8-dimethyl-3,7- nonadienyl)-2H,5H-pyran [3,2-c] [1]} benzopyran-5-one $(\mathbf{8})$

Colorless oil, $[\alpha]_{\mathrm{D}}-68.5^{\circ}\left(c 0.07, \mathrm{CHCl}_{3}\right)$; UV $(\mathrm{MeOH}) \lambda_{\max } \mathrm{nm}(\log \varepsilon) 370$ (sh), 350 (3.5), 293 (3.7), 251 (3.9), 208 (4.6); IR (KBr) $v_{\max } 3430$, 1720, 1650, 1610, 1460, 920, $760 \mathrm{~cm}^{-1} ;{ }^{1} \mathrm{H}$ NMR see Table III; EIMS $m / z$ (rel. int.): $376\left[\mathrm{M}-\mathrm{H}_{2} \mathrm{O}\right]^{+}$ (2), $325\left[\mathrm{M}-\mathrm{C}_{5} \mathrm{H}_{9}\right]^{+}$(10), 227 (42), 149 (4), 135 (37), 107 (12), 83 (7), 69 (37), 41 (100).

3,4-Dihydro-3-hydroxy-2,6-dimethyl-2-(5-methyl4-hexenyl)-2H,5H-pyran [2,3-b] [1] benzopyran5-one (9)

Colorless oil, $[\alpha]_{\mathrm{D}}-20.9^{\circ}\left(c 0.22, \mathrm{CHCl}_{3}\right)$; UV $(\mathrm{MeOH}) \lambda_{\max } \mathrm{nm}(\log \varepsilon) 310$ (sh), 297 (3.8), 276 (3.9), 228 (4.3), 202 (4.2); IR (KBr) $v_{\max } 3460$, 1650, 1630, 1570, 1460, $766 \mathrm{~cm}^{-1} ;{ }^{1} \mathrm{H}$ and ${ }^{13} \mathrm{C}$ NMR see Tables II and III; EIMS $\mathrm{m} / z$ (rel. int.): 328 $[\mathrm{M}]^{+}(3), 259\left[\mathrm{M}-\mathrm{C}_{5} \mathrm{H}_{9}\right]^{+}(1), 219$ (7), 190 (16), 188 (7), 135 (20), 69 (52), 41 (100); HREIMS m/z. $[\mathrm{M}]^{+}$: calcd. for $\mathrm{C}_{20} \mathrm{H}_{24} \mathrm{O}_{4}, 328.1675$; found, 328.1683 . 


\section{Bioautographic assays}

Solutions of compounds $\mathbf{1}, \mathbf{2}, \mathbf{4}$ and $\mathbf{6}$ at a concentration of $10 \mathrm{mgml}^{-1}$ in $\mathrm{CH}_{2} \mathrm{Cl}_{2}$. Of these solutions, $10 \mu \mathrm{l}$ were applied on a TLC plate using graduated capillaries. After application of the samples $(100 \mu \mathrm{g} / \mathrm{spot})$ on a silica gel $60 \mathrm{~F}_{254} \mathrm{Al}$ sheet (Merck), the plate was sprayed with a suspension of C. cucumerinum (DSM 62122) in a nutritive medium (Schlegel, 1992) and incubated for 2-3 days at room temperature in a glass box with a moist atmosphere. Clear inhibition zones appeared against a dark gray background. Benomyl was used as a reference compound.

\section{Acknowledgements}

This work was partially supported by the SeCTER, Universidad Nacional de Jujuy. We also wish to thank CONICET and the Universidad de Buenos Aires for partial financial support. We are indebted to UMYMFOR (CONICET-FCEN, UBA) for NMR spectra and LANAIS-EMAR (CONICET-FCEN, UBA) for mass spectra. We are also grateful to Ing. Novara of the Facultad de Ciencias Naturales, Universidad de Salta for the taxonomic identification of Mutisia friesiana. M. S. M. is a Research Member of the National Research Council of Argentina (CONICET).
Appendino G., Garibaldi P., and Nano G. M. (1983), Isomeric hydroxyperoxyeudesmanolides from Artemisia umbelliformis. Phytochemistry 22, 2767-2772.

Appendino G., Tagliapietra S., Nano G. M., and Picci V. (1988), Ferprenin, a prenylated coumarin from Ferula communis. Phytochemistry 27, 944-946.

Amico V., Oriente G., Neri P., Piatelli M., and Ruberto G. (1987), Tetraprenyltoluquinols from the brown alga Cystoseira stricta. Phytochemistry 26, 1715-1718.

Balbaa S. I., Halim A. F., Halaweish F. T., and Bohlmann F. (1980), New 5-methylcoumarin derivatives from Ethulia conyzoides. Phytochemistry 19, 1519-1522.

Bittner M., Japukovic J., Bohlmann F., Grenz M., and Silva M. (1988), 5-Methylcoumarins and chromones from Triptilion species. Phytochemistry 27, 32633266.

Bittner M., Silva M., Rozas Z.Z., Papastergiou F., and Jakupovic J. (1994), Sesquiterpenes and other constituents from chilean Mutisieae. Phytochemistry 36, $695-698$.

Bohlmann F. and Zdero C. (1977), Neue 5-alkylcumarine und chromone aus Bothriocline laxa. Phytochemistry 16, 1261-1263.

Bohlmann F., Japukovic J., Misra L. N., and Castro V. (1985), 5-Methylcumarin-Derivate aus Lycoseris latifolia. Liebigs Ann. Chem. 1367-1376.

Breitmaier E. and Voelter W. (1987), Carbon-13 NMR Spectroscopy. VCH, New York, USA.

Giberti G. C. (1983). Herbal Folk Medicinal in Northwestern Argentina. J. Ethnopharmacol. 7, 321-341.

Hoeneisen M., Hernández V., Becerra J., Silva M., Bittner M., and Jakupovic J. (1999), 5-Methyl coumarins and a new phenol from Nassauvia pyramidalis and $N$. digitata. Phytochemistry 52, 1667-1669.

Homans A. L. and Fuchs A. (1970), Direct bioautography on thin-layer chromatograms as a method for detecting fungitoxic substances. J. Chromatog. 51, 327329.

Jakupovic J., Boeker R., Schuster A., Bohlmann F., and Jones S. B. (1987), Further guaianolides and 5-alkylcoumarins from Gutenbergia and Bothriocline species. Phytochemistry 26, 1069-1075.
Loyola L. A., Pedreros S., and Morales G. (1985), p-Hydroxyacetophenone derivatives from Senecio graveolens. Phytochemistry 24, 1600-1602.

Mahmoud A. A., Ahmed A. A., Iinuma M., and Tanaka T. (1998), Further monoterpene 5-methylcoumarins and acetophenone derivatives from Ethulia conyzoides. Phytochemistry 48, 543-546.

Moreira D. L., Guimarães E. F., and Kaplan M. A. C. (1998), Non polar constituents from leaves of Piper lhotzkyanum. Phytochemistry 49, 1339-1342.

Murray R. D. H., Méndez J., and Brown S. A. (1982), The Natural Coumarins: Occurrence, Chemistry and Biochemistry. John Wiley \& Sons. New York. USA.

Pritschow P., Jakupovic J., Bohlmann F., Bittner M., and Niemeyer H. (1991), Highly oxygenated sesquiterpenes from Polyachyrus sphaerocephalus and further constituents from Chilean Mutisieae. Phytochemistry 30, 893-898.

Schlegel H. G. (1992), Allgemeine Mikrobiologie. Georg Thieme Verlag, Stuttgart, pp. 192-194.

Torrado Truiti I. M. C. and Sarragiotto A. M. H. (1998), Three 5-methylcoumarins from Chaptalia nutans. Phytochemistry 47, 97-99.

Viturro C., Molina A., and Schmeda-Hirschmann G. (1999), Free radical scavengers from Mutisia friesiana (Asteraceae) and Sanicula graveolens (Apiaceae). Phytother. Res. 13, $422-424$.

Viturro C. I. and de la Fuente J. R. (2000), Chemical study of essential oil of Mutisia friesiana. Molecules 5, $568-570$.

Viturro C. I., Maier M. S., Stortz C. A., and de la Fuente J. R. (2001), Antifungal diastereomeric furanones from Mutisia friesiana: structural determination and conformational analysis. Tetrahedron Asymm. 12, 991-998.

Zdero C., Bohlmann F., King R., and Robinson H. (1986), Further 5-Methyl coumarins and other constituents from the subtribe Mutisiinae. Phytochemistry 25, 509-516.

Zdero C., Bohlmann F., and Solomon J. (1988), Further 5-methylcoumarin derivatives from Mutisia orbignyana. Phytochemistry 27, 891-897. 